\title{
Expression of the Human C-fms Proto-oncogene Product (Colony-stimulating Factor-1 Receptor) on Peripheral Blood Mononuclear Cells and Choriocarcinoma Cell Lines
}

\author{
Carl W. Rettenmier, Rosalba Sacca,‡ Wayne L. Furman, * Martine F. Roussel, Jeffrey T. Holt,\$ Arthur W. Nienhuis,\$ \\ E. Richard Stanley,‡ and Charles J. Sherr \\ Departments of Tumor Cell Biology and ${ }^{*}$ Hematology/Oncology, St. Jude Children's Research Hospital, Memphis, Tennessee 38105; \\ $\ddagger$ Department of Microbiology and Immunology, and Department of Cell Biology, Albert Einstein College of Medicine, \\ Bronx, New York 10461; and §Clinical Hematology Branch, National Heart, Lung, and Blood Institute, \\ National Institutes of Health, Bethesda, Maryland 20205
}

\begin{abstract}
The c-fms gene product is related, and possibly identical, to the receptor for the mononuclear phagocyte colony stimulating factor, CSF-1. Using antisera to a recombinant $v$-fms-coded polypeptide, glycoproteins encoded by the human c-fms locus were detected in mononuclear cells from normal peripheral blood and in promyelocytic HL-60 cells $24 \mathrm{~h}$ after induction of monocytic differentiation with phorbol ester. The 150-kD human c-fms-coded glycoprotein was expressed at the cell surface, was active as a tyrosine-specific protein kinase in vitro, and shared primary structural features with the product of the feline retroviral $v$-fms oncogene. A biochemically indistinguishable glycoprotein was detected in human choriocarcinoma cell lines. Like peripheral blood mononuclear cells and phorbol ester-treated HL-60 cells, the choriocarcinoma cells expressed high affinity binding sites for human CSF-1. In addition to serving as a lineage specific growth factor in hematopoiesis, CSF-1 may play a role in normal trophoblast development.
\end{abstract}

\section{Introduction}

The colony-stimulating factor, CSF-1, ' is a hematopoietic growth factor required for the proliferation, differentiation, and survival of cells of the mononuclear phagocyte series (1). Cells of this lineage (including determined precursors, monoblasts, promonocytes, monocytes, and macrophages) express a single class of high affinity receptors for CSF-1 (2-4). Although the CSF-1 receptor is expressed by less mature bone marrow progenitors, the number of receptors per cell increases about 10 -fold as the cells become committed to the mononuclear phagocyte lineage (5). Thus, circulating peripheral blood monocytes express relatively high numbers of CSF-1 receptors, and the populations of CSF-1-binding cells in spleen, lymph nodes, and inflammatory exudates correspond in their number and morphology to macrophages $(2,6)$. By these criteria, the expression of the CSF-1

Received for publication 4 December 1985.

1. Abbreviations used in this paper: CSF-1, colony-stimulating factor 1; DMSO, dimethylsulfoxide; HCG, human chorionic gonadotropin; MEM, Iscove's modified Eagle's minimal essential medium; SM-FeSV, feline sarcoma virus; TPA, 12-O-tetradecanoyl-phorbol-13-acetate.

J. Clin. Invest.

(c) The American Society for Clinical Investigation, Inc. 0021-9738/86/06/1740/07 \$1.00

Volume 77, June 1986, 1740-1746 receptor represents a differentiation specific marker of cells of the mononuclear phagocyte lineage.

The purified murine CSF-1 receptor is a $165-\mathrm{kD}$ glycoprotein with an associated tyrosine-specific protein kinase activity (7, 8 ), and is similar in its properties to the product of a feline protooncogene, c-fms (9). Indeed, the c-fms proto-oncogene product is preferentially expressed at high levels in feline and murine macrophages, specifically binds CSF-1, and, in the presence of the growth factor, is phosphorylated on tyrosine in membrane preparations (10). Moreover, the product of the feline retroviral oncogene, v-fms, retains a CSF-1 binding domain so that v-fmstransformed fibroblasts express high affinity binding sites for the growth factor (11). These results strongly suggest that the product of the c-fms proto-oncogene and the CSF-1 receptor are closely related, and possibly identical, molecules (10).

Transcripts of c-fms RNA have been detected in spleen, lymph nodes, liver (9), bone marrow and peripheral blood mononuclear cells $(12,13)$ and in human tumors of various histologic types (14). This pattern of gene expression is consistent with the tissue distribution of normal CSF-1 receptor-bearing cells of the mononuclear phagocyte lineage and with infiltration of tumor tissues by inflammatory cells. However, c-fms transcripts have also been detected at comparatively high levels in placental tissues (15) and in a human choriocarcinoma cell line established from malignant placental trophoblasts (16). The latter observations prompted us to examine the c-fms gene product in choriocarcinoma cell lines and to compare its properties to the c-fms-coded glycoprotein expressed in normal human peripheral blood mononuclear cells. The c-fms gene products in both cell types are biochemically indistinguishable, and the cells express high affinity binding sites for human CSF-1.

\section{Methods \\ Cell lines. The derivation and properties of mink lung cells nonproduc- tively transformed by the Susan McDonough strain of feline sarcoma virus (SM-FeSV) have been previously described (17). The human BeWo (18) and JEG-3 (19) choriocarcinoma cell lines were obtained from the American Type Culture Collection, Rockville, MD. BeWo cells secrete human chorionic gonadotrophin (HCG), human placental lactogen, and steroid hormones, and JEG cells produce HCG, steroid hormones, and human chorionic somatomammotrophin. Both cell lines have the mor- phologic appearance of undifferentiated trophoblasts, and JEG-3 cells form choriocarcinomas when injected into nude mice. BeWo cells were maintained in RPMI 1640 medium containing $15 \%$ fetal bovine serum. JEG-3 and the promyelocytic leukemia cell line, HL-60 (20) were main- tained in Iscove's modified Eagle's minimal essential medium (MEM) (Gibco, Grand Island, NY) containing 20\% fetal calf serum. HL-60 cells were induced to monocytic differentiation by treatment with $12-O$-te- tradecanoyl-phorbol-13-acetate (TPA) (21) or to granulocytic differen-}


tiation by dimethylsulfoxide (DMSO) (22). TPA and DMSO were purchased from Sigma Chemical Co. (St. Louis, MO). Human leukemic cell lines of erythroid (K562), myeloid (KG-1 and KG-1a) and monocytic (U937) lineages, and leukemic lymphoid cells of the pre-B (NALM-1), B (Daudi, Raji) or T (MOLT-4) series were provided by Dr. J. Mirro of St. Jude Children's Research Hospital.

Peripheral blood cell fractions. Fresh peripheral blood mononuclear cells, granulocytes, and erythrocytes were prepared as described by others $(23,24)$. Blood from normal volunteers was collected by venipuncture in the presence of heparin and mixed with an equal volume of Hanks' balanced salts solution (HBSS) at $4^{\circ} \mathrm{C}$. The samples were divided into 40-ml aliquots, each of which was layered over $10 \mathrm{ml}$ Ficoll-Hypaque (Pharmacia Fine Chemicals, Piscataway, NJ) in 50-ml polypropylene tubes, and then centrifuged at $1,250 \mathrm{rpm}$ for $30 \mathrm{~min}$ at $4^{\circ} \mathrm{C}$. Mononuclear cells were collected from the interface, washed in HBSS, and examined morphologically in cytospin preparations; this fraction consisted primarily of lymphocytes with typically 5-10\% monocytes and $1 \%$ or fewer granulocytes. For CSF-1 binding assays, the mononuclear cells were used directly or were seeded into $35-\mathrm{mm}$ culture dishes $\left(4 \times 10^{6}\right.$ cells/dish) and cultured at $37^{\circ} \mathrm{C}$ in $\alpha$-MEM; after $2 \mathrm{~h}$, the nonadherent cells were removed and the adherent cells cultured for an additional $17 \mathrm{~h}$. Erythrocytes and granulocytes recovered from the Ficoll-Hypaque pellets were resuspended in HBSS containing 4\% Dextran and subjected to unit gravity sedimentation at $4^{\circ} \mathrm{C}$ for $2 \mathrm{~h}$. The granulocyte-rich supernatant was then collected, centrifuged into a pellet, washed twice with $10 \mathrm{mM} \mathrm{KHCO}_{3}$ (pH 7.4) containing $155 \mathrm{mM} \mathrm{NH}_{4} \mathrm{Cl}$ and $0.1 \mathrm{mM}$ EDTA to lyse erythrocytes, resuspended in HBSS and examined morphologically; this fraction typically consisted of 90-95\% granulocytes and up to $10 \%$ lymphocytes. Erythrocytes were recovered from the pellet of the unit gravity sedimentation step. A platelet fraction was prepared by differential centrifugation (25).

Cell surface radioiodination. Cells were washed twice with phosphatebuffered saline (PBS) and incubated in $1.0 \mathrm{ml}$ of PBS containing $5 \mathrm{mM}$ D-glucose, $1.0 \mathrm{mCi}$ carrier-free $\mathrm{Na}{ }^{125} \mathrm{I}$ (Amersham Corp., Arlington Heights, IL), $75 \mu \mathrm{g}$ lactoperoxidase and $8.8 \mu \mathrm{g}$ glucose oxidase (Sigma Chemical Co., St. Louis, MO) for $15 \mathrm{~min}$ at $22^{\circ} \mathrm{C}$ with occasional gentle mixing. The cells were then washed twice in ice-cold PBS and lysed in RIPA buffer ( $50 \mathrm{mM}$ Tris- $\mathrm{HCl}, \mathrm{pH} 7.4,150 \mathrm{mM} \mathrm{NaCl}, 20 \mathrm{mM}$ EDTA, $1 \%$ Triton $\mathrm{X}-100,1 \%$ sodium deoxycholate, $0.1 \%$ sodium dodecyl sulfate [SDS]) containing 2\% Aprotinin and $1 \mathrm{mM}$ phenylmethyl sulfonyl fluoride as protease inhibitors. Immune precipitation with rabbit antisera to a recombinant $v$-fms-coded polypeptide (10) was carried out as previously described (26).

Other analytical methods. The procedures for metabolic radiolabeling of cell lines, preparation of cell lysates, the immune complex kinase assay, tryptic peptide analysis (26), digestion of immune precipitates with glycosidic enzymes, and phosphoamino acid analysis (9) have been previously described in detail elsewhere. For phosphoamino acid analysis, ${ }^{32} \mathrm{P}$-labeled polypeptides were hydrolyzed in $6 \mathrm{~N} \mathrm{HCl}$ by heating for $2 \mathrm{~h}$ in a boiling water bath. The products were separated by electrophoresis in two dimensions and detected by autoradiography. During hydrolysis, some ${ }^{32} \mathrm{P}$-labeled protein is degraded to inorganic phosphate, whereas incompletely hydrolyzed phosphopeptides are also detected. To identify the positions of individual phosphoamino acids the autoradiogram spots were aligned with internal standards run on the same chromatogram and visualized by ninhydrin staining.

Binding of ${ }^{125} I$-human CSF-1 to cells. Stage V human urinary CSF1 was purified, iodinated, and further purified by immunoaffinity chromatography as described (27). The specific radioactivity of the purified ${ }^{125} \mathrm{I}-\mathrm{CSF}-1$ used for the binding studies was $1.5 \times 10^{4} \mathrm{cpm} / \mathrm{ng}$ protein. Binding studies with either nonadherent or adherent cells were carried out at $2^{\circ} \mathrm{C}$ in $25 \mathrm{mM}$ Hepes, $0.02 \%$ bovine serum albumin in $\alpha$-MEM lacking bicarbonate, $\mathrm{pH} 7.4(6,27)$. Cells were incubated with $10 \mathrm{nM}$ ${ }^{125} \mathrm{I}-\mathrm{CSF}-1$ for $4 \mathrm{~h}$ with or without a 2-h preincubation with $10 \mathrm{nM}$ CSF1. Separation of cell-bound ${ }^{125} \mathrm{I}-\mathrm{CSF}-1$ from free ${ }^{125} \mathrm{I}-\mathrm{CSF}-1$ in incubations with nonadherent cells $\left(400 \mu 1,4 \times 10^{5}\right.$ cells $\left./ \mathrm{ml}\right)$ was achieved by centrifugation $\left(400 \mathrm{~g}, 15 \mathrm{~min}, 4^{\circ} \mathrm{C}\right)$ of $325 \mu$ of the incubation mixture through $175 \mu \mathrm{l}$ of horse serum. For incubations with adherent cells, the supernatant medium was removed and the monolayer washed five times with ice-cold PBS and solubilized with $5 \%$ SDS in $50 \mathrm{mM}$ Tris- $\mathrm{HCl}, \mathrm{pH}$ 7.4. The cell-associated radioactivity was determined in a gamma counter. Autoradiography of the nonadherent and adherent cells was carried out as described $(2,6)$.

\section{Results}

Human c-fms products are expressed in peripheral blood mononuclear cells and in TPA-induced HL-60 cells. Rabbit antisera to a recombinant $\mathrm{v}$-f $m s$ coded polypeptide synthesized in bacteria reacted specifically with c-fms-coded gene products expressed in normal feline and murine macrophages and precipitated the bona fide murine CSF-1 receptor (10). The same antisera were found to precipitate antigenically crossreactive molecules from human peripheral blood cells. Fig. $1 A$ shows the results of immune complex kinase assays prepared from lysates of fractionated normal human blood cells. Two polypeptides of $150 \mathrm{kD}$ and $130 \mathrm{kD}$ were phosphorylated in immune complexes prepared from peripheral blood mononuclear cells (lane 2) but were not

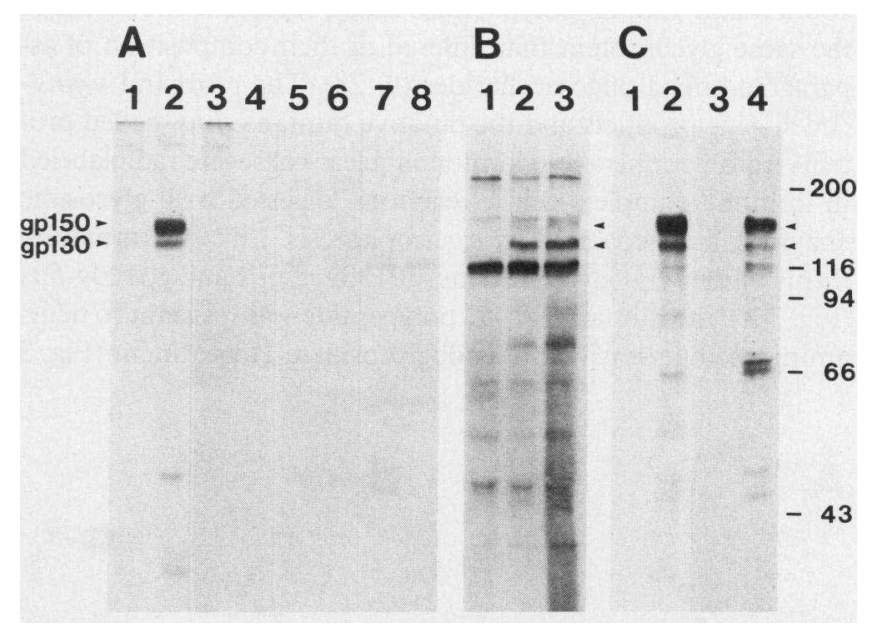

Figure 1. Detection of the human c-fms proto-oncogene product by an immune complex kinase reaction. Detergent lysates of the indicated cells were incubated with either preimmune rabbit serum or antiserum to a recombinant $\mathrm{v}-\mathrm{fms}$-coded polypeptide (bp81 v-fms) expressed in Escherichia coli. Washed immunoprecipitates were assayed for endogenous protein kinase activity, and the products were separated by SDS polyacrylamide gel electrophoresis and detected by autoradiography. $(A)$ Normal human peripheral blood cell fractions were assayed for cfms associated kinase activity: mononuclear cells (lanes $l$ and 2), granulocytes (lanes 3 and 4), erythrocytes (lanes 5 and 6), and a platelet fraction (lanes 7 and 8 ). Immune complexes were prepared using preimmune serum (lanes 1, 3, 5, and 7) or antiserum to bp81 v-fms (lanes 2, 4, 6, and 8). Reactions in lanes $1-6$ were performed with lysates of $1 \times 10^{8}$ fresh cells from each of the indicated fractions. Exposure time for autoradiography was $60 \mathrm{~min}$. (B) HL-60 leukemic cells, either untreated (lane 1 ) or treated with TPA for 24 (lane 2) and $48 \mathrm{~h}$ (lane 3), were assayed for c-fms associated kinase activity in immune complexes prepared with antiserum to bp81 v-fms. Reactions in each lane were prepared from $1.5 \times 10^{7}$ cells. Exposure time, $120 \mathrm{~min} .(C)$ Human choriocarcinoma cell lines were assayed in immune complexes prepared with preimmune serum (lanes 1 and 3 ) or antiserum to bp81v-fms (lanes 2 and 4). Reactions were performed with lysates of $4 \times 10^{6}$ BeWo cells (lanes 1 and 2) or $2 \times 10^{7}$ JEG-3 cells (lanes 3 and 4 ). Exposure time, $30 \mathrm{~min}$. The electrophoretic mobilities of the human c-fms-coded glycoproteins, gp150 and gp130 (left margin), and protein standards of known molecular weight (right margin) are noted. 
detected in precipitates prepared with nonimmune serum (lane 1). These polypeptides were not observed in immune complex kinase assays performed with granulocytes (lanes 3 and 4), erythrocytes (lanes 5 and 6 ) or platelets (lanes 7 and 8 ). Extensive manipulation of fresh human or feline mononuclear cells leads to the loss of c-fms-coded kinase activity. When adherent human peripheral blood cells were studied, there was no enrichment of immunoprecipitable kinase activity as compared to that in the total mononuclear cell population. These results appear to reflect the instability of the kinase, but based on these experiments, we cannot exclude the presence of the c-fms gene product in the nonadherent population. Two-dimensional phosphoamino acid analysis showed that both polypeptides were phosphorylated on tyrosine. (See Fig. $2 \mathrm{~A}$ for representative results with the $150 \mathrm{kD}$ polypeptide.) The detection of these polypeptides with specific antiserum to the $v-f m s$ gene product, their activity as substrates for an associated tyrosine kinase in vitro, and their restricted expression in peripheral blood mononuclear cells suggested that they represented products of the human c-fms gene.

By analogy with the feline $v-f m s$-coded glycoproteins and c- $f m s$-coded products of cats and mice, we suspected that the $130-\mathrm{kD}$ and $150-\mathrm{kD}$ polypeptides might represent two forms of the same glycoprotein that differed in their composition of asparagine-linked oligosaccharides $(9,28)$. The retroviral v-fmscoded gene products and the putative human c-fms-coded proteins from peripheral blood mononuclear cells were radiolabeled in immune complex kinase reactions, digested with glycosidic enzymes, and separated by electrophoresis. Like the immature forms of the viral glycoproteins, gP180gag-fms and gp120v-fms (Fig. $3 \mathrm{~A}$ ), the human $130-\mathrm{kD}$ polypeptide was resistant to neuraminidase but sensitive to endoglycosidase $\mathrm{H}$ treatment (Fig. 3

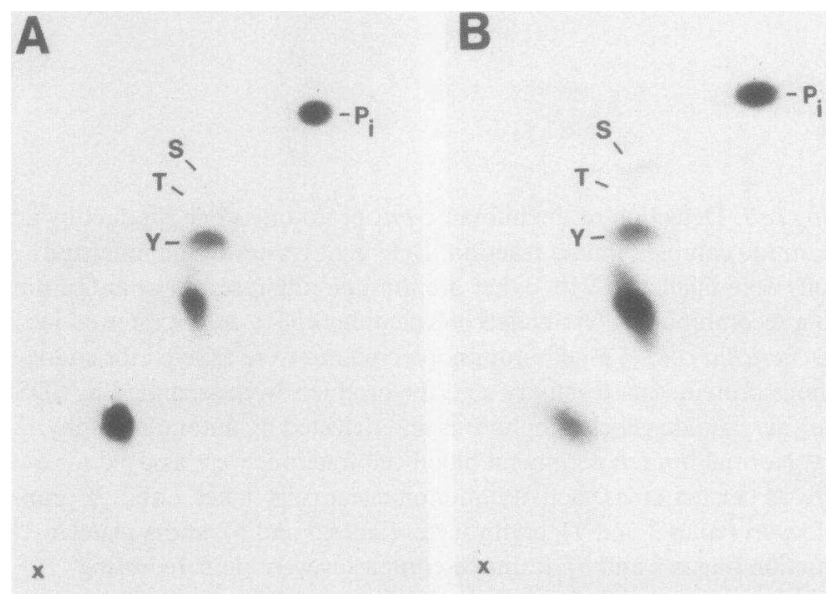

Figure 2. Phosphoamino acid analyses of c-fms-coded 150-kD substrates phosphorylated in immune complex kinase reactions of human peripheral blood mononuclear cells $(A)$ or BeWo choriocarcinoma cells $(B) .{ }^{32} \mathrm{P}$-labeled proteins were eluted from gel slices, hydrolyzed in acid, and subjected to thin-layer electrophoresis in two dimensions.

The origin (X) is at the lower left corner of each panel. Authentic nonradiolabeled phosphoserine (S), phosphothreonine (T), and phosphotyrosine $(\mathrm{Y})$ were included as internal standards. The identity of radiolabeled phosphoamino acids was determined by superimposing the autoradiogram over the ninhydrin-stained standards. The mobility of orthophosphate $\left(\mathbf{P}_{\mathbf{i}}\right)$ is noted. Incompletely hydrolyzed phosphopeptides appear as unlabeled spots in the maps. For both proteins, phosphotyrosine is the major product of the immune complex kinase reaction.

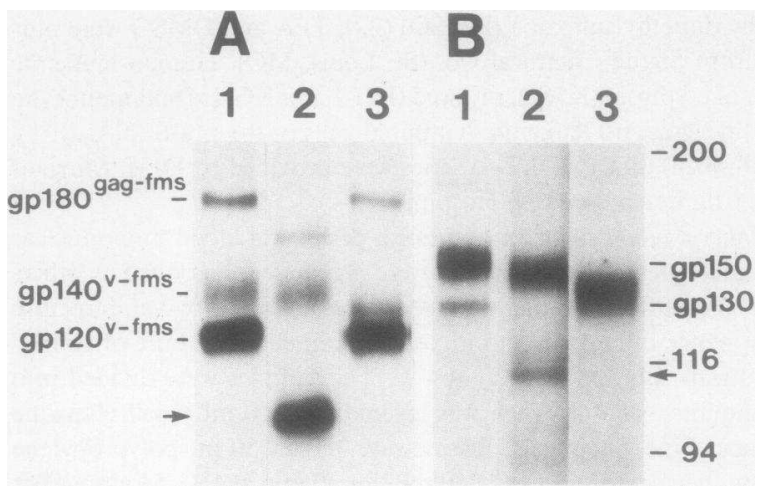

Figure 3. Sensitivity of ${ }^{32} \mathrm{P}$-labeled glycoproteins encoded by v-fms $(A)$ and human c-fms $(B)$ to digestion by glycosidic enzymes. The polypeptides were phosphorylated in immune complex kinase reactions and then incubated for $18 \mathrm{~h}$ at $37^{\circ} \mathrm{C}$ in $25 \mu$ l of buffer containing either no added enzyme (lane 1$), 7.5 \mathrm{mU}$ of endoglycosidase $\mathrm{H}$ (lane 2), or $25 \mathrm{mU}$ of neuraminidase (lane 3). Products were analyzed by electrophoresis in a $6 \%$ polyacrylamide slab gel. The figure is a composite of lanes run on the same gel, and only the relevant portion of the autoradiogram is shown. The electrophoretic mobilities of protein standards of known molecular weight are indicated in kilodaltons at the right margin. The mobilities of undigested (lane 1 ) $\mathrm{v}-\mathrm{fms}$ and human c-fms-coded glycoproteins are also noted in the left and right margins, respectively. The arrows in the margins indicate the deglycosylated bands derived from gp120v-fms (left) and human gp130c-fms (right) after treatment with endoglycosidase $\mathrm{H}$ (see lane 2 of the respective panel).

$B$ ), showing that it contained mannose-rich oligosaccharide chains characteristic of intracellular glycoproteins. By contrast, the mature cell surface form of the viral glycoprotein, gp140vfms (Fig. $3 \mathrm{~A}$ ), and the human 150-kD polypeptide were sensitive to neuraminidase, demonstrating the presence of terminal sialic acid residues. The human $150-\mathrm{kD}$ glycoprotein also showed a slight decrease in apparent molecular weight after endoglycosidase $\mathrm{H}$ treatment (Fig. $3 \mathrm{~B}$, lane 2), indicating that at least some oligosaccharide chains were not processed to endo H-resistant structures. Taken together, the results are consistent with the possibility that the $130-\mathrm{kD}$ glycoprotein is an immature glycosylated precursor of the mature $150-\mathrm{kD}$ molecule. The estimated molecular weight of the deglycosylated polypeptide derived by endo $H$ treatment of the human $130-\mathrm{kD}$ glycoprotein was about $10 \mathrm{kD}$ higher than that of the corresponding form derived from gp 120v-fms (see arrows in the margins of Fig. 3). This suggests that the polypeptide chain of the human c-fms gene product is longer than that of the viral transforming protein.

The human promyelocytic cell line, HL-60, differentiates to adherent macrophage-like cells after treatment with phorbol esters (21) and to granulocytic cells after treatment with DMSO (22). Transcripts of the c-fms gene have been detected approximately $12 \mathrm{~h}$ after TPA treatment when the cells attach to culture dishes and begin to assume a macrophage morphology; by contrast, c-fms RNA is not induced by DMSO $(12,13)$. Control and TPA-treated HL-60 cells were tested for expression of the presumptive c-fms gene products using the immune complex kinase reaction. As shown in Fig. $1 B$, the $130-\mathrm{kD}$ and $150-\mathrm{kD}$ polypeptides were detected in HL-60 cells both $24 \mathrm{~h}$ (lane 2) and $48 \mathrm{~h}$ (lane 3) after TPA treatment. Neither of the polypeptides was detected after induction of granulocytic differentiation with DMSO (data not shown). By comparison to the levels of 
c-fms-coded polypeptides in normal peripheral blood mononuclear cells, the levels of the $130-\mathrm{kD}$ and $150-\mathrm{kD}$ polypeptides in HL-60 cells were significantly lower. Moreover, the $130-\mathrm{kD}$ polypeptide was the major form detected in HL-60 cells throughout the duration of treatment with TPA. The same result was observed in the human U937 histiocytic lymphoma cell line (29) when induced to monocytic differentiation (data not shown). The predominance of the immature form of the c-fms gene product could reflect the failure of these cells to differentiate completely in culture, or alternatively, could be due to the continued presence of an inducing stimulus throughout the duration of the experiments. Neither the 130 - nor $150-\mathrm{kD}$ polypeptide was detected in immune complex kinase assays performed with established lines of erythroid or granulocytic leukemic cells or with several human B or T lymphoid lines (see Methods).

Detection of the c-fms-coded products in choriocarcinoma cell lines. By Northern blotting analysis using a v-fms-specific probe and by nuclease protection experiments performed with a probe derived from the human c-fms locus, we confirmed previously published results of others that a prototypic $\sim 4-\mathrm{kb}$ cfms polyadenylated RNA is expressed at high levels in placenta and in choriocarcinoma cell lines $(15,16)$. We therefore used the immune complex kinase reaction to screen two human choriocarcinoma cell lines, BeWo and JEG-3, for expression of cfms-related gene products. Fig. $1 C$ shows that the $150-\mathrm{kD}$ and $130-\mathrm{kD}$ polypeptides could be specifically precipitated from both cell lines and were active as substrates for an associated tyrosine kinase in vitro. These molecules were the same size as those precipitated from peripheral blood cells (Fig. $1 A$ ) and were phosphorylated on tyrosine residues (Fig. $2 B$ ). Digestion with glycosidic enzymes demonstrated that both forms were glycoproteins indistinguishable from the analogous products expressed on peripheral blood mononuclear cells (see Fig. $3 \mathrm{~B}$ ).

To compare regions of primary structure adjacent to sites of phosphorylation in vitro, ${ }^{32} \mathrm{P}$-labeled molecules phosphorylated in immune complex kinase reactions were digested with trypsin, and the resulting peptides were separated in two dimensions by electrophoresis and chromatography. As shown in Fig. 4, $A$ and $B$, the labeled tryptic phosphopeptides of the human $150 \mathrm{kD}$ proteins from both peripheral blood mononuclear cells and choriocarcinoma cells were identical. The $130-\mathrm{kD}$ proteins from both sources yielded the same labeled peptides (data not shown). Moreover, several of the phosphopeptides comigrated with those derived from the v-fms-coded glycoprotein, gp140v$f m s$ (Fig. $4 C$ ). A major ${ }^{32} \mathrm{P}$-labeled tryptic peptide unique to the retroviral protein (see schematic diagram in Fig. $4 \mathrm{D}$ ) maps to its extracellular aminoterminal domain (Rettenmier, C. W., unpublished data), whereas the location of the major tryptic phosphopeptide unique to the human protein has not been determined.

A comparison of $\left[{ }^{35}\right.$ S]methionine-labeled tryptic peptides from the 150-kD glycoprotein expressed in BeWo cells (Fig. 5 $A$ ) with those derived from virus-coded gp 140v-fms (Fig. $5 \mathrm{~B}$ ) also suggested that the proteins had related primary structures. A mixing experiment (Fig. $5 C$ ) confirmed the presence of a subset of comigrating peptides as well as unique methioninecontaining peptides derived from each molecule (see diagram in Fig. $5 \mathrm{D}$ ). The peptides unique to the viral product were not resolved in the peptide maps because they did not migrate in the chromatography solvent; these peptides are derived from the extracellular domain of gp140v-fms and are probably glycosylated (Rettenmier, C. W., unpublished data). Based on their

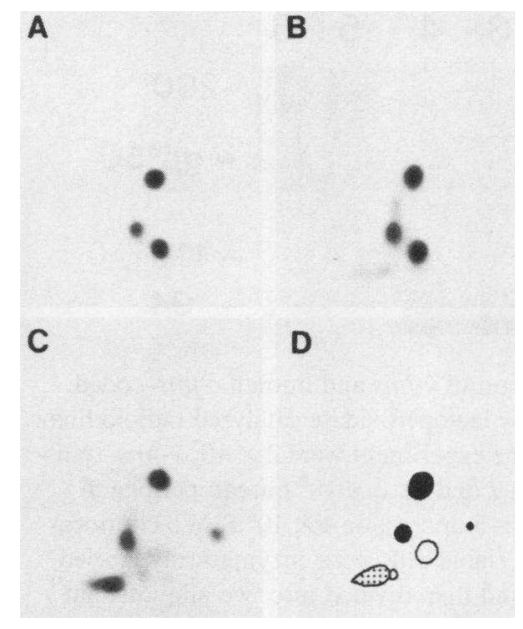

Figure 4. Two-dimensional separation of tryptic ${ }^{32} \mathrm{P}$-labeled phosphopeptides derived from v-fms- and human c-fms-coded substrates phosphorylated in the immune complex kinase reaction. Peptides were spotted on cellulose-coated thin-layer plates at the lower left corner of each panel and then subjected to electrophoresis at $\mathrm{pH} 1.9$ from left (anode) to right followed by ascending chromatography. $(A) \mathrm{Hu}$ man peripheral blood mononuclear cell $150-\mathrm{kD}$ protein, $(B)$ BeWo cell $150-\mathrm{kD}$ protein, $(C)$ gp 140v-fms. $(D)$ is a composite drawing based on mixing experiments and shows those tryptic phosphopeptides common to v-fms and human c-fms products $(\cdot)$, those unique to the human protein $(0)$ and those unique to the v-fms-coded glycoproteins $(\odot)$.

structural and biochemical properties, we conclude that the 150$\mathrm{kD}$ proteins expressed in choriocarcinoma cell lines are authentic c-fms gene products.

Human gp150c-fms is expressed at the cell surface. The mature form of the retroviral glycoprotein, gp140v-fms, is expressed at the surface of transformed cells, where it can be detected by peroxidase- or fluorescent-labeled antibody conjugates $(26,28$, $30,31)$. To test for expression of c-fms-coded molecules on the surfaces of human cells, live peripheral blood mononuclear cells and BeWo cells were enzymatically radioiodinated, and after detergent lysis, labeled molecules from the plasma membrane were precipitated with antiserum. Fig. 6 (lanes 1 and 2) shows that when this technique was applied to virus-transformed cells, only ${ }^{125} \mathrm{I}$-labeled gp 140v-fms was detected $(28,30)$. A radiolabeled

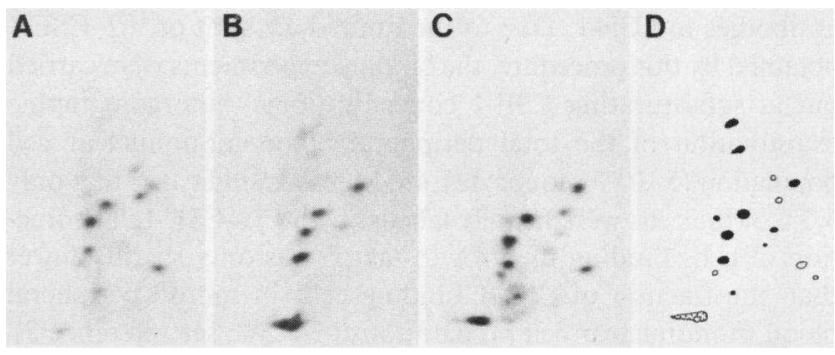

Figure 5. Two-dimensional tryptic peptide analysis of $\left[{ }^{35} \mathrm{~S}\right] \mathrm{methionine-}$ labeled v-fms- and human c-fms-coded glycoproteins. (A) Human BeWo cell gp150, $(B)$ gp140v-fms, $(C)$ mixing experiment of tryptic peptides from BeWo cell gp150 and gp140v-fms, (D) schematic diagram showing methionine-containing tryptic peptides shared between gp140v-fms and BeWo cell gp150 (•), peptides unique to BeWo cell gp150 (०), and those unique to gp140v-fms (๑). 


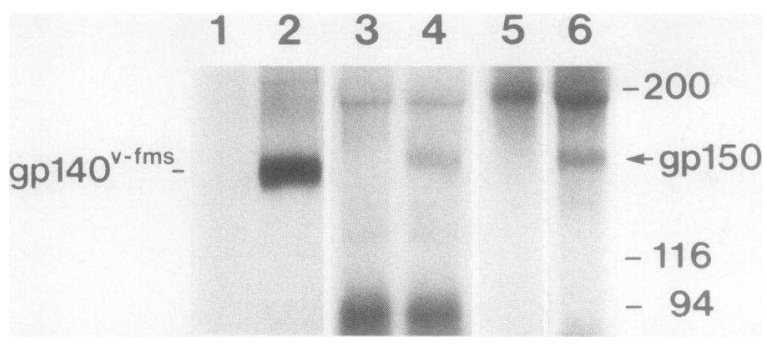

Figure 6. Cell surface expression of v-fms and human c-fms-coded glycoproteins demonstrated by lactoperoxidase catalyzed radioiodination. Cell numbers used for the experiment were $2 \times 10^{7} \mathrm{v}$-fms-transformed mink lung cells (lanes 1 and 2), $2 \times 10^{8}$ human peripheral blood mononuclear cells (lanes 3 and 4 ), or $4 \times 10^{6}$ BeWo choriocarcinoma cells (lanes 5 and 6 ). Viable cells were enzymatically labeled with ${ }^{125} \mathrm{I}$, lysed in detergent, and then divided into two aliquots that were immunoprecipitated either with preimmune rabbit serum (lanes 1,3 , and 5) or with antiserum to a recombinant v-fms-coded polypeptide (lanes 2, 4, and 6). Labeled proteins were separated by SDS polyacrylamide gel electrophoresis and detected by autoradiography. The figure is a composite of lanes run on the same gel, and only the relevant portion of the autoradiogram is shown. The mobilities of protein standards of known molecular weight are indicated in kilodaltons at the right margin, and the mobilities of gp $140 \mathrm{v}-\mathrm{fms}$ and the human gp150c-fms product are also noted.

product of $150 \mathrm{kD}$ was specifically precipitated from human peripheral blood mononuclear cells (lane 4) and from BeWo cells (lane 6), but was not detected with preimmune serum (lanes 3 and 5 , respectively). This polypeptide was not evident in immunoprecipitates prepared from TPA-treated HL-60 cells (data not shown), as predicted from the low levels of its expression seen in the immune complex kinase assay (Fig. $1 B$ ). Also consistent with the results of metabolic labeling and immune complex kinase assays, the human c- $f m s$-coded glycoproteins were detected at significantly lower levels than their viral counterparts. The human c-fms-coded glycoprotein of $130 \mathrm{kD}$ was not detected at the cell surface in agreement with the previous findings that it lacked mature $\mathrm{N}$-linked oligosaccharide chains (Fig. 3).

Human peripheral blood monocytes and choriocarcinoma cells bind CSF-1. To determine whether cells producing the human c-fms gene product also expressed receptors for CSF-1, binding studies with the radiolabeled growth factor were performed. Human CSF-1 was partially purified from urine, radiolabeled with ${ }^{125} \mathrm{I}$, and the labeled growth factor was recovered by affinity chromatography using columns prepared with specific antibodies to CSF-1. Due to the limited amount of ${ }^{125}$ I-CSF-1 obtained by this procedure, the binding experiments were carried out at subsaturating CSF-1 concentrations. Autoradiographic examination of the total peripheral blood mononuclear cell population (5-10\% monocytes; see Methods) indicated that only $3.5 \%$ of the cells were heavily labeled with ${ }^{125}$ I-CSF-1. The fraction of cells binding the growth factor was only slightly lower than the fraction of CSF-1 binding cells in mouse peripheral blood mononuclear cell preparations ( $\sim 7.5 \%$; see reference 3 ). When adherent peripheral blood mononuclear cells were isolated and tested for ligand binding using $10 \mathrm{nM}$ CSF-1, these cells specifically bound $\sim 40,000{ }^{125}$ I-CSF-1 molecules per cell, and the bound ${ }^{125} \mathrm{I}-\mathrm{CSF}-1$ did not dissociate during a 6-h incubation at $2^{\circ} \mathrm{C}$ in the absence of the growth factor.

Similar results were obtained with BeWo cells, which bound $\sim 32,000{ }^{125}$ I-CSF-1 molecules per cell. Again, binding was ir- reversible, and no dissociation of the bound ligand was detected after $6 \mathrm{~h}$ at $2^{\circ} \mathrm{C}$ in the absence of free CSF-1. In contrast, only about 1,500 CSF-1 binding sites per cell were detected under the same conditions using TPA-induced, adherent HL-60 cells. Thus, the extent of binding of CSF-1 correlated with the level of expression of $\mathrm{gp} 150 \mathrm{c}-\mathrm{fm} s$ in the different cell populations.

\section{Discussion}

Antisera to a recombinant $\mathrm{v}-\mathrm{fms}$-coded polypeptide reacted with glycoproteins of $150 \mathrm{kD}$ and $130 \mathrm{kD}$ in lysates of human peripheral blood monocytes, TPA-induced HL-60 cells, and two human choriocarcinoma cell lines. Based on their antigenic crossreactivity with the v-fms gene product, their activities as substrates for an associated tyrosine kinase in immune complexes, and comparative analyses of methionine-containing and phosphorylated tryptic peptides, both polypeptides were shown to be products of the human c-fms gene. Like the retroviral gene products, gp 120v-fms and gp 140v-fms, gp 130c-fms and gp 150cfms differ in their composition of asparagine-linked oligosaccharide chains, and only the larger species is expressed at the cell surface. These results suggest that gp130c-fms represents an immature form of the glycoprotein which is processed during intracellular transport to yield the mature cell surface glycoprotein, gp150c-fms. The molecular weight of the deglycosylated human c-fms polypeptide appears to be about $10 \mathrm{kD}$ higher than the analogous viral protein. Recent nucleotide sequence analysis predicts that the human c-fms product differs from the virus-coded glycoprotein at its carboxylterminal end and contains additional C-terminal amino acids (32; Browning, P., H. F. Bunn, and $A$. W. Nienhuis, unpublished data). The carboxylterminal truncation of the v-fms gene product may be sufficient to account for the apparent molecular weight difference between it and the c-fms-coded polypeptide. However, since gP140v-fms is generated by proteolytic cleavage of a viral polyprotein precursor (gP180gag-fms), the extent of aminoterminal amino acid sequence homology between gp140v-fms and gp150c-fms also depends on post-translational processing events.

Expression of the c-fms gene product on the surfaces of human peripheral blood mononuclear cells was expected, based on the tissue-specific expression of c-fms in the feline system, and the recently defined relationship between the murine c-fmscoded glycoprotein and the receptor for CSF-1 (10). Similarly, c-fms transcripts were previously detected in TPA-treated HL60 cells after they had differentiated to postmitotic, adherent macrophage-like cells $(12,13)$. Unlike the results obtained with normal peripheral blood mononuclear cells, reduced levels of gp 150c-fms relative to gp130c-fms were seen in TPA-treated HL60 cells. These results might reflect the failure of HL-60 cells to differentiate completely in culture or the possibility that phorbol esters downregulate expression of CSF-1 receptors, reducing the binding of CSF-1 to macrophages (33). Taken together, the above results are consistent with the conclusion that c-fms expression in adult tissues is restricted to cells of the mononuclear phagocyte lineage. However, c-fms transcripts (16) and protein products were also detected in choriocarcinoma cell lines derived from placental trophoblasts. Although expression of the c-fms gene products in choriocarcinoma cell lines could be related to transformation of trophoblastic cells, c-fms RNA is expressed at relatively high levels in normal placental tissues as well (15). Therefore, it seems more likely that the c-fms gene product plays a physiologic role in the placenta. 
The relationship of the murine c-fms gene product to the CSF-1 receptor (10) and the recent demonstration that the vfms oncogene product can itself bind murine CSF-1 (11) together suggested that human cells expressing gp150c-fms at their surface would specifically bind the growth factor. Purified murine CSF1 does not bind to high affinity receptors on human mononuclear phagocytes nor support their growth in culture (1), and the limited availability of human CSF-1 precluded detailed studies of its binding to the different human cell populations. However, a comparison of the number of human CSF-1 molecules bound per adherent monocyte ( $\sim 40,000$ binding sites per cell) with the number of binding sites for murine CSF-1 on mouse bone marrow-derived macrophages ( $\sim 50,000$ per cell; see reference 4) suggested that almost all the CSF-1 sites on human peripheral blood monocytes were occupied under the binding conditions used. Furthermore, the binding was irreversible at $2^{\circ} \mathrm{C}$, as observed for the binding of CSF-1 to murine cells (4), consistent with an interaction of the ligand with a high affinity receptor. Under the same conditions, the degree of ${ }^{125} \mathrm{I}-\mathrm{CSF}-1$ binding by BeWo and TPA-induced HL-60 cells correlated with the levels of expression of gp 150c-fms, with BeWo cells expressing a relatively high number of binding sites and HL-60 cells expressing very few. Although these correlative data strongly suggest that human gp150c-fms is related and possibly identical to the human CSF-1 receptor, the limited availability of the purified human hormone precluded more definitive biochemical assays. For example, purified murine ${ }^{125} \mathrm{I}-\mathrm{CSF}-1$, when bound to its receptor, was precipitated with antibodies to the murine c-fms product and was shown to enhance phosphorylation of the immunoprecipitable receptor on tyrosine (10). Our attempts to generate similar results in the human system were unsuccessful. Since the human CSF-1 gene has been recently cloned and expressed (34), the availability of recombinant human CSF-1 may facilitate such studies.

A clear implication of our data is that CSF-1 could play a role in placental development. Murine CSF-1 levels have been shown to be elevated in uterine tissues during pregnancy (35), and conceivably, uterine CSF-1 could regulate early stages of development with specificity for cells of the fetal placenta that elaborate the receptor. Hence, CSF-1 may stimulate embryonic cells that are not committed to the mononuclear phagocyte lineage.

\section{Acknowledgments}

We thank Dr. Richard A. Ashmun for preparing the peripheral blood cell fractions and Dr. Stephen C. Peiper for advice and assistance with the cell surface radioiodination experiments.

This work was supported by grants CA 38187 (to Dr. Sherr) and CA 26504 (to Dr. Stanley) from the National Cancer Institute; by the American Lebanese Syrian Associated Charities of St. Jude Children's Research Hospital; and by the Albert Einstein College of Medicine Cancer Center Core Grant. Dr. Sacca was supported by National Institutes of Health (NIH) Training Grant CA 09173. Dr. Stanley is a recipient of an Irma T. Hirschl Cancer Scientist Award. Dr. Rettenmier was supported in part by a Biomedical Research Support grant (RR-05584-21) from the NIH.

Note added in proof. Woolford et al. (36) have recently identified the human c-fms gene product in BeWo choriocarcinoma cells and phorbol ester-treated ML-1 cells.

\section{References}

1. Stanley, E. R., L. J. Guilbert, R. J. Tushinski, and S. H. Bartelmez. 1983. CSF-1: a mononuclear phagocyte lineage-specific hemopoietic growth factor. J. Cell. Biochem. 21:151-159.
2. Byrne, P. V., L. J. Guilbert, and E. R. Stanley. 1981. Distribution of cells bearing receptors for a colony-stimulating factor (CSF-1) in murine tissues. J. Cell Biol. 91:848-853.

3. Tushinski, R. J., I. T. Oliver, L. J. Guilbert, P. W. Tynan, J. R. Warner, and E. R. Stanley. 1982. Survival of mononuclear phagocytes depends on a lineage-specific growth factor that the differentiated cells selectively destroy. Cell. 28:71-81.

4. Guilbert, L. J., and E. R. Stanley. 1986. The interaction of ${ }^{125} \mathrm{I}-$ CSF-1 with bone marrow-derived macrophages. J. Biol. Chem. 261: 4024-4032.

5. Bartelmez, S. H., and E. R. Stanley. 1985. Synergism between hemopoietic growth factors (HGFs) detected by their effects on cells bearing receptors for a lineage specific HGF: assay of hemopoietin-1. J. Cell. Physiol. 122:370-378.

6. Guilbert, L. J., and E. R. Stanley. 1980. Specific interaction of murine colony-stimulating factor with mononuclear phagocytic cells. J. Cell Biol. 85:153-159.

7. Morgan, C. J., and E. R. Stanley. 1984. Chemical cross-linking of the mononuclear phagocyte specific growth factor CSF-1 to its receptor at the cell surface. Biochem. Biophys. Res. Commun. 119:35-41.

8. Yeung, Y. G., P. T. Jubinsky, and E. R. Stanley. 1986. Preparation, assay, and characterization of the solubilized CSF-1 receptor. J. Cell. Biochem. In press.

9. Rettenmier, C. W., J. H. Chen, M. F. Roussel, and C. J. Sherr. 1985. The product of the c-fms proto-oncogene: a glycoprotein with associated tyrosine kinase activity. Science (Wash. DC). 228:320-322.

10. Sherr, C. J., C. W. Rettenmier, R. Sacca, M. F. Roussel, A. T. Look, and E. R. Stanley. 1985. The c-fms proto-oncogene product is related to the receptor for the mononuclear phagocyte growth factor, CSF-1. Cell. 41:665-676.

11. Sacca, R., E. R. Stanley, C. J. Sherr, and C. W. Rettenmier. 1986. Specific binding of the mononuclear phagocyte colony stimulating factor, CSF-1, to the product of the v-fms oncogene. Proc. Natl. Acad. Sci. USA. In press.

12. Sariban, E., T. Mitchell, and D. Kufe. 1985. Expression of the c-fms proto-oncogene during human monocytic differentiation. Nature (Lond.). 316:64-66.

13. Nienhuis, A. W., H. F. Bunn, P. H. Turner, T. V. Gopal, W. G. Nash, S. J. O'Brien, and C. J. Sherr. 1985. Expression of the human c-fms proto-oncogene in hematopoietic cells and its deletion in the $5 \mathrm{q}^{-}$ syndrome. Cell. 42:421-428.

14. Slamon, D. J., J. B. deKernion, I. M. Verma, and M. J. Cline. 1984. Expression of cellular oncogenes in human malignancies. Science (Wash. DC). 224:256-262.

15. Müller, R., D. J. Slamon, E. D. Adamson, J. M. Tremblay, D. Muller, M. J. Cline, and I. M. Verma. 1983. Transcription of c-onc genes ${\mathrm{c}-r a s^{\mathbf{k}}}$ and c-fms during mouse development. Mol. Cell. Biol. 3:10621069.

16. Müller, R., J. M. Tremblay, E. D. Adamson, and I. M. Verma. 1983. Tissue and cell type-specific expression of two human c-onc genes. Nature (Lond.). 304:454-456.

17. Ruscetti, S. K., L. P. Turek, and C. J. Sherr. 1980. Three independent isolates of feline sarcoma virus code for three distinct gag-x polyproteins. J. Virol. 35:259-264.

18. Pattillo, R. A., and G. O. Gey. 1968. The establishment of a cell line of human hormone-synthesizing trophoblastic cells in vitro. Cancer Res. 28:1231-1236.

19. Kohler, P. O., and W. E. Bridson. 1971. Isolation of hormone producing clonal lines of human choriocarcinoma. J. Clin. Endocrinol. Metab. 32:683-687.

20. Collins, S. J., R. C. Gallo, and R. E. Gallagher. 1977. Continuous growth and differentiation of human myeloid leukemic cells in suspension culture. Nature (Lond.). 270:347-349.

21. Rovera, G., D. Santoli, and C. Damsky. 1979. Human promyelocytic leukemia cells in culture differentiate into macrophage-like cells when treated with phorbol-diester. Proc. Natl. Acad. Sci. USA. 76:27792783.

22. Collins, S. J., F. W. Ruscetti, R. E. Gallagher, and R. C. Gallo. 
1978. Terminal differentiation of human promyelocytic leukemia cells induced by dimethyl sulfoxide and other polar compounds. Proc. Natl. Acad. Sci. USA. 75:2458-2462.

23. Boyum, A. 1976. Isolation of lymphocytes, granulocytes and macrophages. Scand. J. Immunol. 5(Suppl. 5):9.

24. Levy, P. C., G. M. Shaw, and A. G. LoBuglio. 1979. Human monocyte, lymphocyte, and granulocyte antibody-dependent cell-mediated cytotoxicity toward tumor cells. I. General characteristics of cytolysis. J. Immunol. 123:594-599.

25. Dillard, G. H. L., G. Brecher, and E. P. Cronkite. 1951. Separation, concentration, and transfusion of platelets. Proc. Soc. Exp. Biol. Med. 78:796-799.

26. Roussel, M. F., C. W. Rettenmier, A. T. Look, and C. J. Sherr. 1984. Cell surface expression of v-fms-coded glycoproteins is required for transformation. Mol. Cell. Biol. 4:1999-2009.

27. Stanley, E. R. Macrophage colony stimulating factor. In Methods in Enzymology-Immunochemical techniques, Vol. 116. G. DiSabato, J. J. Langone, and H. Van Vunakis, editors. Academic Press, Inc., New York. 564-587.

28. Anderson, S. J., M. A. Gonda, C. W. Rettenmier, and C. J. Sherr. 1984. Subcellular localization of glycoproteins encoded by the viral oncogene v-fms. J. Virol. 51:730-741.

29. Sundström, C., and K. Nilsson. 1976. Establishment and characterization of a human histiocytic lymphoma cell line (U-937). Int. J. Cancer. 17:565-577.
30. Manger, R., L. Najita, E. J. Nichols, S.-I. Hakomori, and L. Rohrschneider. 1984. Cell surface expression of the McDonough strain of feline sarcoma virus $\mathrm{fms}$ gene product (gp140 fms). Cell. 39:327-337.

31. Rettenmier, C. W., M. F. Roussel, C. O. Quinn, G. R. Kitchingman, A. T. Look, and C. J. Sherr. 1985. Transmembrane orientation of glycoproteins encoded by the v-fms oncogene. Cell. 40:971-981.

32. Coussens, L., C. Van Beveren, D. Smith, E. Chen, R. L. Mitchell, C. M. Isacke, I. M. Verma, and A. Ullrich. 1986. Structural alteration of viral homologue of receptor proto-oncogene $f m s$ at carboxyl terminus. Nature (Lond.). 320:277-280.

33. Chen, B. D.-M., H.-S. Lin, and S. Hsu. 1983. Tumor-promoting phorbol esters inhibit the binding of colony-stimulating factor (CSF-1) to murine peritoneal exudate macrophages. J. Cell. Physiol. 116:207212.

34. Kawasaki, E. S., M. B. Ladner, A. M. Wang, J. Van Arsdell, M. K. Warren, M. Y. Coyne, V. L. Schweickart, M.-T. Lee, K. J. Wilson, A. Boosman, E. R. Stanley, P. Ralph, and D. F. Mark. 1985. Molecular cloning of a complementary DNA encoding human macrophage-specific colony stimulating factor (CSF-1). Science (Wash. DC). 230:291-296.

35. Bradley, T. R., E. R. Stanley, and M. A. Summer. 1971. Factors from mouse tissues stimulating colony growth of mouse bone marrow cells in vitro. Aust. J. Exp. Biol. Sci. 49:595-603.

36. Woolford, J., V. Rothwell, and L. Rohrschneider. 1985. Characterization of the human c-fms gene product and its expression in cells of the monocyte-macrophage lineage. Miol. Cell. Biol., 5:3458-3466. 